\title{
Quantifying fecundity in Macoma balthica using an enzyme-linked immunosorbent assay (ELISA)
}

\author{
William Christopher Long ${ }^{1,3, *}$, Erin Bromage ${ }^{2,4}$, Rochelle D. Seitz $^{1}$, Stephen Kaattari $^{2}$ \\ ${ }^{1}$ Dept. of Biological Sciences, and ${ }^{2}$ Dept. of Environmental and Aquatic Animal Health, School of Marine Science, \\ Virginia Institute of Marine Science, The College of William and Mary, PO Box 1346, Gloucester Pt., Virginia 23062, USA \\ ${ }^{3}$ Present address: Smithsonian Environmental Research Center, 647 Contees Wharf Road, PO Box 28, Edgewater, \\ Maryland 21037, USA
}

${ }^{4}$ Present address: Department of Biology, University of Massachusetts, 285 Old Westport Rd., North Dartmouth, Dartmouth, Massachusetts 02747, USA

\begin{abstract}
Monoclonal antibodies specific to a heat shock protein 70-like protein expressed in the eggs of Macoma balthica (mb-HSP70) were employed to develop an enzyme-linked immunosorbent assay (ELISA) to quantify fecundity in females. The assay was specific to egg tissue, with no demonstrable reactivity with juvenile or male tissues. The concentration of mb-HSP70 increased as the female gonads matured, necessitating the determination of a calibration curve for future experiments. The number of eggs in females was positively correlated with body mass index (BMI), and clams with a BMI <1.4 did not produce eggs. The estimated number of eggs per clam during the fall spawning period was similar to that observed in eastern North Atlantic populations in clams of similar size; clams with shell lengths from 16 to $18 \mathrm{~mm}$ had from 7000 to 60000 eggs apiece. Larger clams had up to 450000 eggs. This assay effectively quantifies eggs at any stage of gonadal development in which eggs can be distinguished microscopically and is easier and cheaper to perform than other techniques of comparable precision.
\end{abstract}

KEY WORDS: Macoma balthica $\cdot$ Fecundity $\cdot$ Egg $\cdot$ ELISA $\cdot$ Monoclonal antibodies $\cdot$ Heat shock protein

\section{INTRODUCTION}

The tellenid clam Macoma balthica is a small, thinshelled clam common in estuaries in both the eastern and western North Atlantic. In the Chesapeake Bay, it is the biomass-dominant organism in mesohaline, muddy habitats, comprising up to $85 \%$ of the biomass (Holland et al. 1977). In the Chesapeake, $M$. balthica is an important link in the food web, as a variety of piscine and crustacean predators prey upon it; $M$. balthica comprises approximately $50 \%$ of the blue crab Callinectes sapidus diet alone (Hines et al. 1990). In eastern North Atlantic estuaries, it is an important food supply for migratory shorebirds (Stillman et al. 2005). It is considered an indicator of ecosystem health, as it is relatively sensitive to stressors such as eutrophication and hypoxia (Seitz et al. 2003, Powers et al. 2005).
The reproductive cycle of Macoma balthica has been well studied, although its seasonality varies among populations. In the Chesapeake, M. balthica spawn in both the fall and spring (Shaw 1965), whereas in Massachusetts and in the eastern North Atlantic they only spawn in the early spring (Gilbert 1978, Honkoop \& van der Meer 1998). M. balthica invests heavily in eggs, producing large, energy-rich eggs with high lipid content that can account for $>30 \%$ of their mass (Honkoop et al. 1999). Reproductive output varies with water temperature (Honkoop \& van der Meer 1998), food quality (Hendriks et al. 2003), and the body mass index (BMI) of the clam (Beukema et al. 2001).

Estimating the reproductive success of an individual is difficult, especially for broadcast-spawning marine invertebrates, such as Macoma balthica, because of the many factors that affect fertilization success and 
the survival and successful settling of larvae. The number of eggs successfully fertilized is dependent, not only on the number spawned, but also on the timing of spawning (i.e. synchronized spawning), the population density, environmental conditions, such as water flow, turbulence, and quality, and other factors (Levitan 1995). Once fertilized, the embryos and later larvae must face mortality from such factors as physiological stress, starvation, and predators before they can successfully settle and recruit (Morgan 1995). Because of the difficulty in measuring these processes, the reproductive potential of an individual is often estimated as the fecundity or number of gametes present in the individual prior to spawning (e.g. Kang et al. 2003b), though this may be an overestimate, as some eggs may be reabsorbed by the female prior to spawning (e.g. Al-Mohanna et al. 2003).

Measuring fecundity in Macoma balthica and in other bivalves is difficult, and various methods have been used. Visual examination and ranking of gonadal fullness is an easy, but highly qualitative measurement (e.g. Gilbert 1978, De Goeij \& Honkoop 2003). Tissue sectioning and manual counting of eggs under a microscope is more quantitative, but labor intensive (e.g. Kang et al. 2003a). A common technique used with $M$. balthica is induction of spawning via temperature shock, followed by collection and counting of eggs, which is quantitative, but also labor intensive (e.g. Honkoop et al. 1999, Beukema et al. 2001).

An easier technique, enzyme-linked immunosorbent assay (ELISA), has been developed to quantify eggs in a variety of bivalves, including Crassostrea virginica (Choi et al. 1993), Crassostrea gigas (Kang et al. 2003b), Saxidomus purpuratus (Park et al. 2003) and Ruditapes philippinarum (Park \& Choi 2004). ELISAs allow for rapid, simultaneous, quantitative assessments of a large number of samples. In the present study, we developed a sandwich ELISA, using monoclonal antibodies to quantify the number of eggs in Macoma balthica.

\section{MATERIALS AND METHODS}

Production of antibodies and purification of egg protein standard. Monoclonal antibodies to eggspecific proteins in Macoma balthica were produced using subtractive immunization (see Bromage et al. 2008 , in this issue, for detailed methods). Briefly, mice were injected with a crude protein extract of juvenile (i.e. non-reproductive) $M$. balthica homogenized in phosphate-buffered saline (PBS; $8.4 \mathrm{mM} \mathrm{Na}_{2} \mathrm{HPO}_{4}$, $1.6 \mathrm{mM} \mathrm{NaH}_{2} \mathrm{PO}_{4}, 150 \mathrm{mM} \mathrm{NaCl}, \mathrm{pH} 7.2$ ) and centrifuged at $15000 \times g$. Subsequent cyclophosphamide injections killed all proliferating B-cells. The mice were then injected with a crude protein extract of $M$. balthica eggs homogenized in PBS and centrifuged at $15000 \times g$. This technique ensured that any B-cells that proliferated produced antibodies specific to targets unique to the egg extracts (Matthew \& Sandrock 1987). B-cells were isolated and fused with myeloma cells, and the resulting Hybridomas were screened with ELISA against both juvenile and egg extracts to identify positive clones and verify specificity. For this study, we used monoclonal antibody 7A4. We determined, via Western blotting and protein sequencing, that it was specific to a $96 \mathrm{kDa} M$. balthica egg-specific HSP70-like protein (mb-HSP70; Bromage et al. 2008). It was stored at $1 \mathrm{mg}$ antibody $\mathrm{ml}^{-1}$ in $50 \%$ glycerol at $-20^{\circ} \mathrm{C}$.

Ripe female Macoma balthica were collected from the York River, Chesapeake Bay on 23 October 2003 and stored at $-20^{\circ} \mathrm{C}$ before use. In this collection, as in all others, we collected more clams than we thought we would need (typically 50 to 150 clams collection ${ }^{-1}$ ), and we sexed them in the laboratory when required. An egg protein standard was made by incising and squeezing the gonads to collect eggs. The eggs from 3 females were pooled, homogenized in PBS, and centrifuged at $15000 \times g$ for $1 \mathrm{~h}$ at $4^{\circ} \mathrm{C}$. The supernatant was collected and the protein concentration was determined with a bicinchoninic acid assay (BCA; Sigma) using bovine serum albumin as the standard. The egg

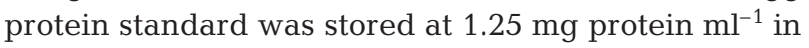
$1 \mathrm{ml}$ aliquots at $-20^{\circ} \mathrm{C}$. In the present paper, concentrations of mb-HSP70 will be expressed in 'units', where 1 unit of mb-HSP70 is equal to the concentration of mbHSP70 in $1 \mathrm{ml}$ of $1.0 \mathrm{mg} \mathrm{ml}^{-1}$ egg protein standard. When the first standard ran low, a second was made using 3 ripe females collected on 30 October 2005. The same procedure was followed as above, and the concentration of mb-HSP70 in the new standard was determined by ELISA (see the following subsection).

ELISA. The following ELISA protocol we developed and used to analyze all samples. ELISAs were run in 96-well polystyrene micro-plates, and all incubations were executed at $37^{\circ} \mathrm{C}$. The primary antibody, $100 \mu \mathrm{l}$ of $7 \mathrm{~A} 4$ at $2 \mu \mathrm{g} \mathrm{ml}^{-1}$ in citrate buffer $(10 \mathrm{mM}$ sodium citrate, $\mathrm{pH} 4.0$ ), was added to each well and incubated for $1 \mathrm{~h}$. The wells were then blocked with $240 \mu \mathrm{l}$ of Trisbuffered saline with $0.1 \%$ Tween-20 (TBST; $50 \mathrm{mM}$ Tris, $150 \mathrm{mM} \mathrm{NaCl}, 1 \mathrm{mM}$ EDTA, pH 8.0) with $1 \%$ bovine serum albumin, and incubated for $1 \mathrm{~h}$. Subsequently, $100 \mu \mathrm{l}$ of each undiluted sample together with 1:5 serial dilutions in TBST were analyzed in duplicate. Serial dilutions of the egg standard were also run on every plate. After blocking, the plates were incubated with the sample for $1 \mathrm{~h}$ before being washed 3 times with TBST. Then, $100 \mu \mathrm{l}$ of biotinylated 7A4 (b-7A4; Pierce NHS-biotinylation kit, as per manufacturer's 
instructions) at $2 \mu \mathrm{g} \mathrm{ml}^{-1}$ in TBST was incubated for $1 \mathrm{~h}$ in each well, after which the plates were washed 3 times with TBST, and $100 \mu$ of 1:500 dilution in TBST of $0.125 \mathrm{mg} \mathrm{ml}^{-1}$ strepavidin-conjugated horseradish peroxidase was incubated in each well for $1 \mathrm{~h}$. The plates were washed 3 times in TBST, and $100 \mu l$ 2,2'-azino-bis (3-ethylbenzthiazoline-6 sulfonic acid), ABTS solution $(200 \mu \mathrm{l} 1 \%$ ABTS, $4.8 \mathrm{ml}$ citrate buffer, $10 \mu \mathrm{l} 30 \% \mathrm{H}_{2} \mathrm{O}_{2}$ ) was added to each well. The optical density (OD) at $405 \mathrm{~nm}$ was read using a plate reader (Multiskan MCC EX, Thermo Electron Co.). Multiple readings were done, and the maximum rate of change in $\mathrm{OD}$ in each well was calculated. A non-linear regression was performed for each sample to find the least sum-of-squares fit for Eq. (1):

$$
\text { rate }=\frac{R_{\max }}{1+\left(\frac{C}{C_{50}}\right)^{S}}
$$

where 'rate' is the rate of OD change in each well, $C$ is the sample concentration, $R_{\max }$ is the maximum rate, $C_{50}$ is the concentration at which the rate is $50 \%$ of $R_{\max }$ and $s$ is the slope coefficient. Since the concentration of mb-HSP70 at $C_{50}$ was the same among samples, knowing the concentration of mb-HSP70 at $C_{50}$ in the standard solution and the level of dilution at $C_{50}$ for each of the samples allows the calculation of the concentration of mb-HSP70 in the undiluted sample (Ottinger et al. 2001).

Verifying specificity of an ELISA. We used ELISA to determine the concentration of mb-HSP70 in gonadal and somatic tissue, and in male and female clams to ensure that the mb-HSP70 was only present in female reproductive tissue. Ripe Macoma balthica, i.e. clams heavy with eggs or sperm, were collected from the York River on 23 October 2003, 30 September 2005, 30 October 2005, and 29 November 2005 and stored at $-20^{\circ} \mathrm{C}$ before use. The clams were sexed (Gilbert 1978), and the following tissues were excised: (1) female somatic tissue from 3 clams (including samples of mantle, siphon, abductor muscle, foot muscle, and viscera); (2) female gonadal tissue (including eggs from 18 clams); and (3) male gonadal tissue from 6 clams. Each tissue sample was homogenized in PBS and centrifuged at $15000 \times g$ for $1 \mathrm{~h}$ at $4^{\circ} \mathrm{C}$. The supernatant was collected and centrifuged a second time for further clarification at $15000 \times g$ for $1 \mathrm{~h}$ at $4^{\circ} \mathrm{C}$, and the supernatant was collected. Protein concentration was determined for each extract using the BCA assay as above, and the extracts were stored at $-20^{\circ} \mathrm{C}$. The concentration of mb-HSP70 in each sample was determined by ELISA and standardized by dividing the concentration of mb-HSP70 by the total concentration of protein.

Quantification of eggs at different stages of gonadal development and in different years. In order to deter- mine if the ELISA could be used to quantify eggs, we established the relationship between mb-HSP70 concentration and egg concentration for clams at different stages of gonadal development and in different years. Ripe female Macoma balthica were collected in the York River on 23 October 2003 (5 clams), 30 September 2005 (2 clams), 30 October 2005 (3 clams), and 29 November 2005 (8 clams) and stored at $-20^{\circ} \mathrm{C}$ until used. Each clam was opened, its gonads incised, and samples of eggs extracted. Five clams were used from 23 October 2003, 2 from 30 September 2005, 3 from 30 October 2005, and 8 from 29 November 2005. The eggs were placed in PBS and gently suspended by repeated pipetting. The concentration of eggs in each sample was determined with a hemocytometer. M. balthica eggs are $\sim 100 \mu \mathrm{m}$ in diameter (Hendriks et al. 2003), so $15 \mu \mathrm{l}$ of the egg suspension was placed on the hemocytometer; this was then covered with the cover slip and eggs were counted. We did 2 counts of each sample and took the average. Eggs could not be distinguished in clams sampled on 23 October 2003, so samples of the gonads were taken and analyzed with ELISA as below, but they were not included in the statistical analysis. The samples were centrifuged at $15000 \times g$ for $5 \mathrm{~min}$, and the pellet was homogenized. The homogenates were centrifuged at $15000 \times g$ for $30 \mathrm{~min}$, and the supernatant was collected and stored at $-20^{\circ} \mathrm{C}$. The concentration of mb-HSP70 in each sample was determined by ELISA. Total protein concentration was determined for each sample with the BCA assay as above, and the amount of protein per egg was calculated and statistically analyzed with a 1-way analysis of variance (ANOVA) with date (30 October 2005 and 29 November 2005) as the factor (all ANOVA-type analyses performed with Minitab v.15.1). The concentration of mb-HSP70 was regressed (linear, leastsquares, all regression analyses were performed with SigmaPlot v.10.0) against the known concentration of eggs for each sampling period. The ratio of mbHSP70:total protein (units mb-HSP70 $\mathrm{mg}^{-1}$ total protein) was calculated for the egg samples in October and November of 2005. These were compared to those calculated for the male gonadal and female somatic tissues (previous section) with a 1-way ANOVA and a Tukey's test. All samples were $\log \left(\mathrm{N}+10^{-4}\right)$ transformed to achieve homogeneity of variance prior to analysis.

Relationship between fecundity and BMI. Ripe female Macoma balthica collected on 30 October 2005 and 29 November 2005 were used to determine the relationship between fecundity and BMI. The shell length was measured with calipers to the nearest $0.1 \mathrm{~mm}$, and the clams were opened and homogenized in $15 \mathrm{ml}$ PBS. Homogenates were centrifuged at $3000 \times g$ for $1 \mathrm{~h}$, after which $1 \mathrm{ml}$ of supernatant was 
removed and the concentration of mb-HSP70 was determined by ELISA. The number of eggs in each clam was determined using the relationship previously determined between the concentration of mb-HSP70 and egg concentration. The rest of the sample was dried at $65^{\circ} \mathrm{C}$ and the dry mass was determined. The BMI (dry mass length ${ }^{-3}$ in $\mathrm{mg} \mathrm{cm}{ }^{-3}$; Honkoop \& Beukema 1997), also known as the condition index (Bonsdorff \& Wenne 1989), was calculated for each clam. An analysis of covariance (ANCOVA) was conducted on egg number with date as a factor and BMI as a covariant. Linear regression was used to determine the relationship between the number of eggs in each clam and its BMI.

\section{RESULTS}

The ELISA was specific for female Macoma balthica gonadal tissue (Fig. 1). The non-linear regression was an excellent fit in every case, with $\mathrm{r}^{2}$ values $>0.98$ and $\mathrm{p}$ values $<0.0001$. Small concentrations of mb-HSP70 were detected in female somatic tissues, but the con-

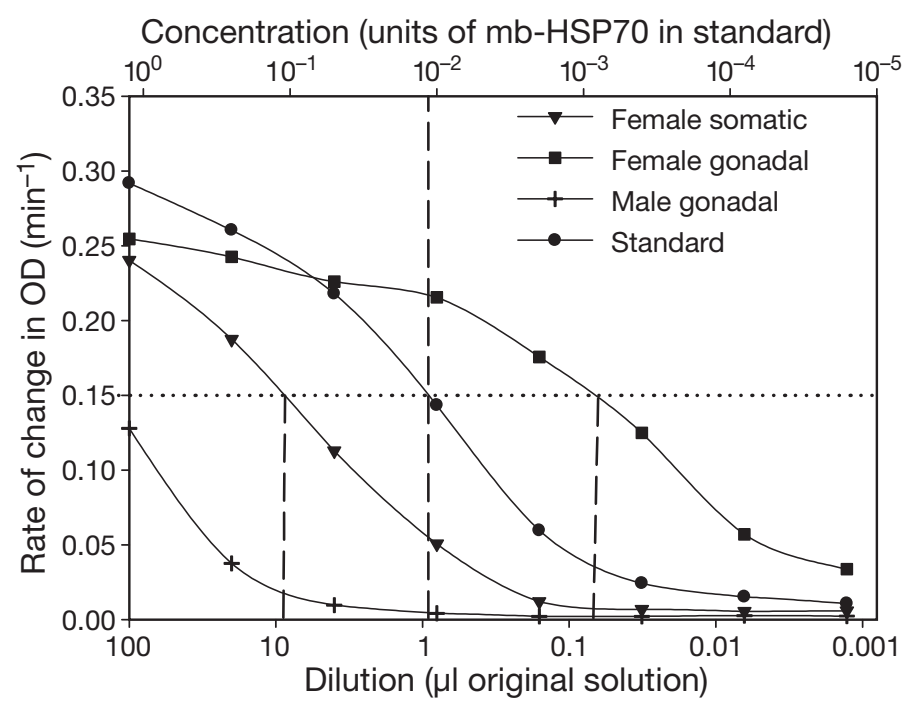

Fig. 1. Macoma balthica. ELISA curves for somatic and gonadal tissues from adult $M$. balthica. The standard line is a plot against both dilution (in $\mu \mathrm{l}$ ) of the original solution (along with the other samples) as well as the concentration of mbHSP70. The dotted horizontal line indicates the rate at $C_{50}$ from the standard curve fit. The dashed vertical lines indicate the approximate $C_{50}$ values for each curve based on the standard $C_{50}$. The $C_{50}$ for each sample has the same concentration of mb-HSP70 as the $C_{50}$ in the standard, so the dilution factor (in $\mu$ l of the original sample) can be used to calculate the concentration of mb-HSP70 in the undiluted sample: standard $\left(C_{50}=1.0 \mu \mathrm{l}, 1.25\right.$ units mb-HSP70 in undiluted sample), female somatic $\left(C_{50}=6.6 \mu \mathrm{l}, 0.19\right.$ units mb-HSP70 in undiluted sample), female gonadal ( $C_{50}=0.038 \mu \mathrm{l}, 33.4$ units mb-HSP70 in undiluted sample), male gonadal (unreliable fit, $C_{50}=$ $\sim 200 \mu \mathrm{l}, \sim 0.006$ units mb-HSP70 in undiluted sample) centrations were 2 orders of magnitude lower than in female gonadal tissue (Fig. 1). Mb-HSP70 was below reliable detection limits in male gonads during all time periods, and our best estimate was 4 to 6 orders of magnitude lower than in female gonads. Western blot analysis (not shown) showed a weak reaction in the stacking gel layer of the polyacrylamide gel, and nothing at $96 \mathrm{kDa}$ (the size of mb-HSP70, Bromage et al. 2008), indicating that the reaction is likely a nonspecific binding of the antibody to large protein aggregates and that mb-HSP70 is not actually present in males.

Clams collected on 30 September 2005 were at an early stage of gonadal development; no eggs could be distinguished microscopically, and ELISA revealed extremely low levels of mb-HSP70 in the gonads, which were equal to the levels observed in male gonads and lower than those observed in female somatic tissue during gametogenesis. At all other time periods (23 October 2003, 30 October 2005, 29 November 2005), the mb-HSP70 concentration was positively correlated with the egg concentration (Fig. 2), although the relationship varied among the time periods. Clams collected on 29 November 2005 were fully mature (visual observation; Gilbert 1978); some had already spawned, as evidenced by empty gonads (Gilbert 1978). In 2005, total protein per egg increased from $0.016 \mu \mathrm{g} \mathrm{egg}^{-1}( \pm 0.002 \mathrm{SE})$ in October to $0.030 \mathrm{ug} \mathrm{egg}^{-1}$ $( \pm 0.005 \mathrm{SE})$ in November $(t$-test; $\mathrm{N}=27 ; t=-2.75 ; \mathrm{p}=$ 0.012). The ratio of mb-HSP70:total protein differed among tissue types (Fig. $3 ;$ ANOVA; $\mathrm{N}=40 ; F_{4,35}=$ $455.73 ; \mathrm{p}<0.0005$ ) and was low in male gonads and in female gonads prior to egg development, intermediate in somatic tissue from ripe females, and highest in female gonads during egg development (Fig. 3).

The number of eggs in female Macoma balthica, ranged from 2500 to 450000 eggs $\mathrm{clam}^{-1}$, and was correlated to BMI (ANCOVA; $\mathrm{N}=40 ; F_{1,38}=11.82 ; \mathrm{p}=$ $0.001)$, but not by month $\left(F_{1,38}=1.227 ; \mathrm{p}=0.276\right)$. Clams that had already spawned contained low levels of mb-HSP70, as expected, and were not included in the analyses. BMI was a good predictor of egg number, and clams with a BMI $<1.4 \mathrm{mg} \mathrm{cm}^{-3}$ did not have any eggs (regression analysis; Fig. 4).

\section{DISCUSSION}

We have developed a simple and rapid assay for the quantification of eggs in female Macoma balthica. ELISAs are a highly quantitative, reliable means to measure concentrations of antigens (e.g. Choi et al. 1993). The ELISA developed in the present study has the added benefit of utilizing monoclonal antibodies, unlike other, similar assays that used polyclonal anti- 

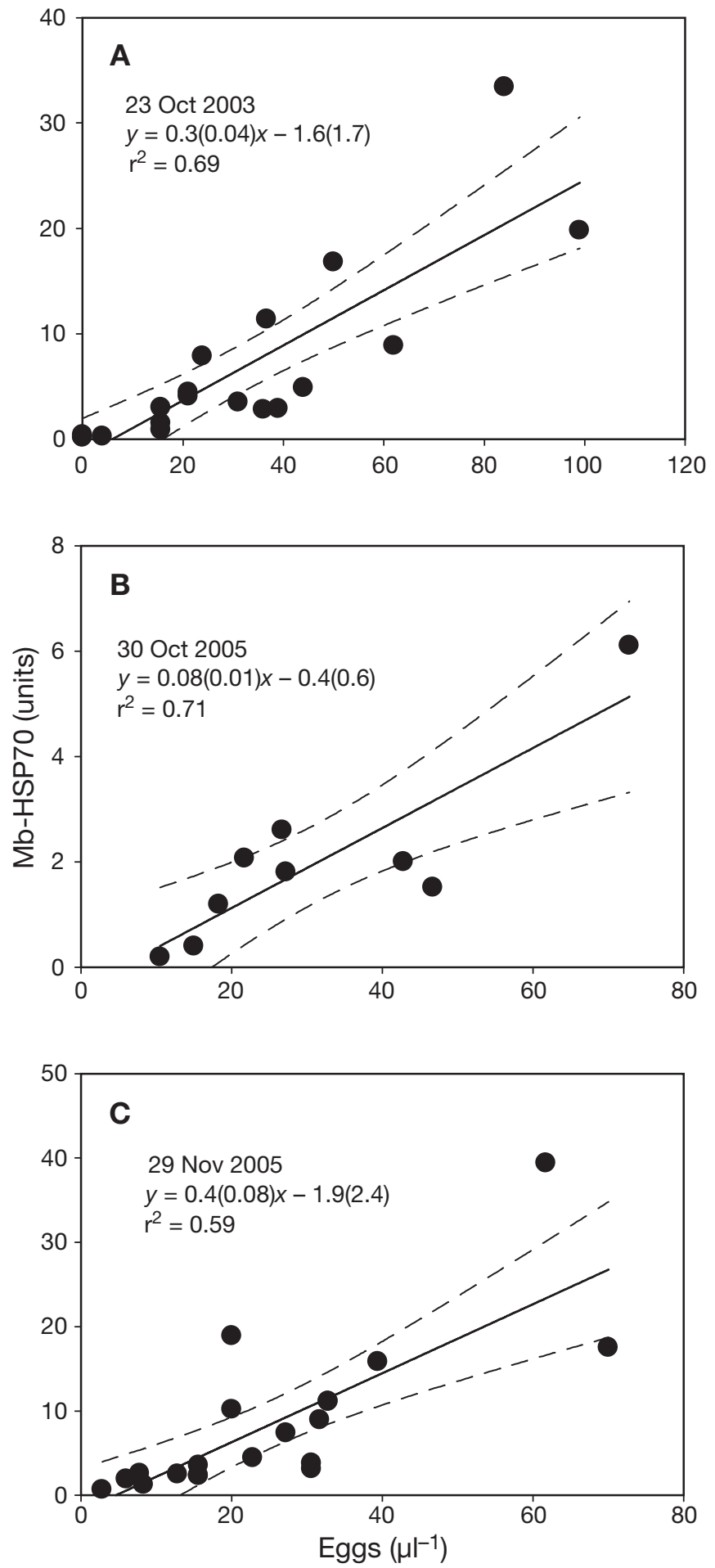

Fig. 2. Macoma balthica. Relationship between egg concentration and mb-HSP70 concentration at 3 different dates: (A) October 2003 (5 clams), (B) October 2005 (3 clams), and (C) November 2005 (8 clams). Equation and solid line represent a least-squares fit ( $p>0.0003$ for all 3 regressions; SE for regression parameters included parenthetically), and dashed lines represent the $95 \%$ confidence intervals for the regressions. Each point represents a sample of eggs taken from a female clam

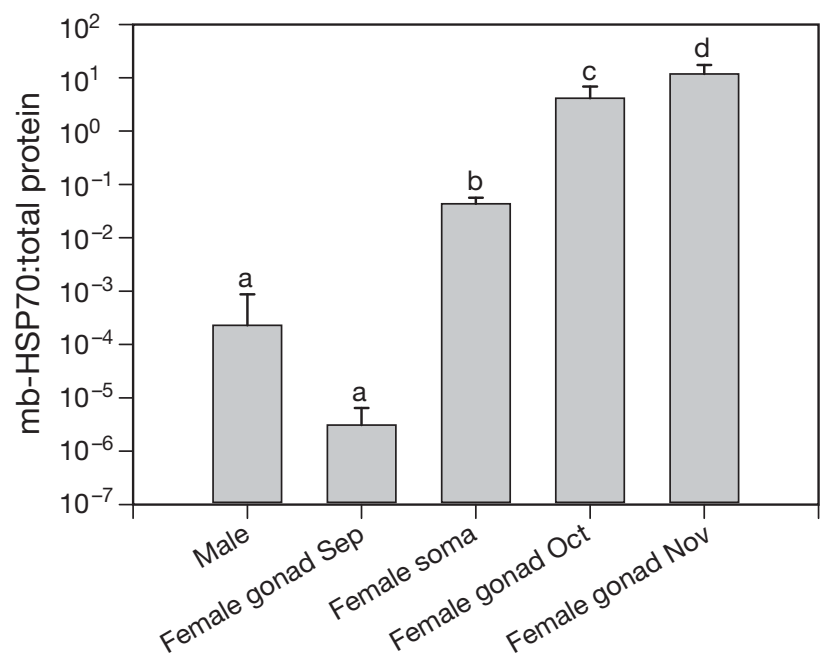

Fig. 3. Macoma balthica. Ratio (mean \pm SD) of mb-HSP70:total protein in $M$. balthica tissues. Samples annotated with different letters differ at the 0.05 level (Tukey's test)

bodies to quantify bivalve eggs (Choi et al. 1993, Kang et al. 2003a,b, Park et al. 2003). Although polyclonal antibodies have similar utility in ELISAs, assays are only reliably comparable if they all use the same batch of antibodies. As polyclonal antibodies can only be produced in limited amounts, sharing between laboratories and comparison of results are likewise limited. This limitation does not exist with monoclonal antibodies; they are produced by an immortal hybridoma cell line that can be used in any laboratory to produce the same antibody, making direct comparison of results possible.

The ELISA in the present study is specific to egg tissue in female Macoma balthica. A small concentration of mb-HSP70 may be present in somatic tissues of ripe females, but this result could be due to the inclusion of a small amount of gonadal tissue in the sample, possibly due to leakage from the gonads during freezing and thawing or because gonads in ripe female $M$. balthica envelop most other tissues (Gilbert 1978), making dissection difficult. Regardless, the concentration of mb-HSP70 in these tissues is low enough that it does not influence the results. Male $M$. balthica and females prior to egg development had concentrations of mb-HSP70 below the reliable limit of this assay. This low level of reactivity in the ELISA, 6 to 7 orders of magnitude lower than that of egg tissue, was likely due to non-specific binding of the antibody to protein aggregates and not to the presence of mb-HSP70.

The concentration of the mb-HSP70 measured by this ELISA was linearly related to egg concentration in samples, and it increases with the maturity of the gonads. This necessitates calibration of the ELISA, 


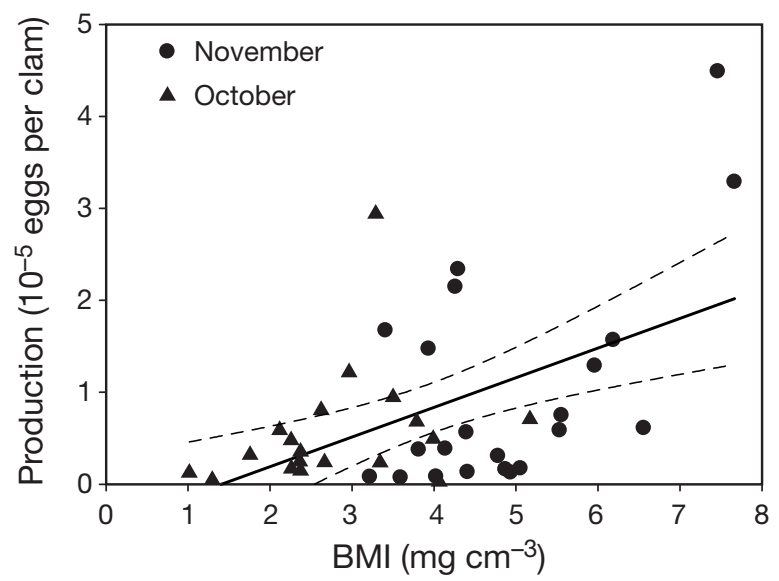

Fig. 4. Macoma balthica. Relationship between body mass index (BMI) and egg production in M. balthica in 2005. The solid line is the least-squares regression $\left(p=0.001 ; r^{2}=0.26\right.$; equation: eggs $=32000 \times \mathrm{BMI}-45000)$, and dashed lines represent the $95 \%$ confidence intervals for the regression

whenever it is used to quantify eggs, by the establishment of an egg concentration to mb-HSP70 concentration curve, as we do here. As this can be reliably done with 10 samples, it is not labor intensive. Without this calibration step, samples taken at the same time and from the same area may be compared with each other, but they cannot be compared with samples from another time or place.

The development of the gonads and eggs in Macoma balthica was similar to that observed in other studies (Shaw 1965, Gilbert 1978). Gonads began to develop in late September, though egg development could not be observed microscopically. Eggs developed between October and November, and spawning occurred in late November. This is later than reported by Shaw (1965), but, as spawning is temperature dependent and our samples were taken far south of those taken by Shaw, this is not surprising. The number of eggs in each clam did not change between October and November, but the total amount of protein in each egg increased, as well as the fraction of mb-HSP70 in that protein. This indicates that as soon as eggs are discernable under a light microscope, they increase in size, but not in number, so the assay can be used at any point during oogenesis without over- or under-estimating the fecundity of a given clam. In November, some clams had high BMIs, but few eggs. Many of these clams were small (16 to $19 \mathrm{~mm}$ ), and some may have already partially spawned (Beukema et al. 2001), explaining the trend. Many potential roles of HSP70 in M. balthica could explain its increase with egg maturity. HSP70 proteins are involved in the folding of newly synthesized proteins and in the transport of proteins across membranes and, thus, are important during oogenesis (Billoud et al. 1993, Bukau \& Horwich 1998). Additionally, an HSP70, not expressed in non-reproductive adult tissues, is linked to meiosis during oogenesis and is essential in mitosis during embryogenesis in the sea urchin Paracentrotus lividus (Sconzo et al. 1999, Geraci et al. 2003).

The number of eggs in Macoma balthica from the Chesapeake increases with clam BMI, and clams with a BMI lower than $\sim 1.4 \mathrm{mg} \mathrm{cm}^{-3}$ do not appear to invest energy in eggs. This is similar to $M$. balthica from the eastern North Atlantic, except that clams from the Chesapeake have a lower BMI (range in the Chesapeake: 1 to 8 [present study]; range in the eastern North Atlantic: 4 to 14 [Beukema et al. 2001]) and are likewise capable of reproduction at a lower BMI (1.4 in the Chesapeake [present study]; 5.5 in the eastern North Atlantic [Honkoop et al. 1999]). This is likely due to differences in growth patterns; $M$. balthica in Europe are wider and broader than those of a similar length in the Chesapeake (Beukema \& Meehan 1985) and have a greater mass (Kamermans et al. 1999), which would result in a lower BMI (they may indeed be a different species; Väinölä 2003). However, M. balthica in both areas have a similar number of eggs at the same size. Our smallest fecund clams (16 to $19 \mathrm{~mm}$ shell length) had between 7000 and 60000 eggs, which is similar to $15 \mathrm{~mm}$ clams from the Wadden Sea that had between 10000 and 90000 eggs (Honkoop \& van der Meer 1998). Many of the clams that had high BMIs but had fewer eggs than expected were these small clams.

\section{CONCLUSIONS}

We present here a new method for quantifying eggs in Macoma balthica. Our technique is accurate, simpler, and cheaper to perform than other methods, and will allow for meaningful comparisons among clams from different systems. This method has been tested thus far only on clams from Chesapeake Bay and is likely applicable to all western North Atlantic populations of $M$. balthica. As genetic differences exist between the western and eastern populations of $M$. balthica (Meehan 1985, Väinölä 2003), the assay still needs to be verified for clams from eastern North Atlantic populations.

Acknowledgements. We thank B. Brylawski and K. Knick for help in field collection of clams, and J. Long, D. Wolcott, and 3 anonymous reviewers whose comments substantially improved the paper. We also thank M. A. Vogelbein and C. Earnhart for help in the laboratory. W.C.L. was supported by a Virginia Institute of Marine Science (VIMS) fellowship and an EPA GRO fellowship. This project was supported by the Commonwealth of Virginia and a grant from the Graduate Student Association of VIMS. This is Contribution 2899 from the Virginia Institute of Marine Science. 


\section{LITERATURE CITED}

Al-Mohanna SY, Al-Rukhais LB, Meakins RH (2003) Oogenesis in Amiantis umbonella (Mollusca: Bivalvia) in Kuwait Bay, Kuwait. J Mar Biol Assoc UK 83:1065-1072

Beukema JJ, Meehan BW (1985) Latitudinal variation in linear growth and other shell characteristics of Macoma balthica. Mar Biol 90:27-33

Beukema JJ, Drent J, Honkoop PJC (2001) Maximizing lifetime egg production in a Wadden Sea population of the tellenid bivalve Macoma balthica: a trade-off between immediate and future reproductive outputs. Mar Ecol Prog Ser 209:119-129

Billoud B, Rodriguez-Martin ML, Berard L, Moreau M, Angelier N (1993) Constitutive expression of a somatic heat-inducible hsp70 gene during amphibian oogenesis. Development 119:921-932

Bonsdorff E, Wenne R (1989) A comparison of condition indices of Macoma balthica (L.) from the northern and southern Baltic Sea. Neth J Sea Res 23:45-55

Bromage E, Long WC, Kaattari S (2008) Biomarkers of oogenesis in Macoma balthica determined by subtractive immunization. Aquat Biol 3:139-145

The application of subtractive immunization in ecological research: production of monoclonal antibodies to egg-specific proteins in Macoma balthica. Aquact Biol (in press)

Bukau B, Horwich AL (1998) The Hsp70 and Hsp60 chaperone machines. Cell 92:351-366

Choi KS, Lewis DH, Powell EN, Ray SM (1993) Quantitative measurement of reproductive ouput in the American oyster Crassostrea virginica (Gmelin) using an enzymelinked immunosorbent assay (ELISA). Aquacult Fish Manage 24:299-322

De Goeij P, Honkoop PJC (2003) Experimental effects of immersion time and water temperature on body condition, burying depth and timing of spawning of the tellenid bivalve Macoma balthica. Helgol Mar Res 57:20-26

Geraci F, Agueli C, Giudice G, Sconzo G (2003) Localization of HSP70, Cdc2, and Cyclin B in sea urchin oocytes in nonstressed conditions. Biochem Biophys Res Commun 210: 748-753

Gilbert MA (1978) Aspects of the reproductive cycle in Macoma balthica (Bivalvia). Nautilus 92:21-24

> Hendriks IE, van Duren LA, Herman PMJ (2003) Effect of dietary polyunsaturated fatty acids on reproductive output and larval growth of bivalves. J Exp Mar Biol Ecol 296: $199-213$

> Hines AH, Haddon AM, Wiechert LA (1990) Guild structure and foraging impact of blue crabs and epibenthic fish in a sub-estuary of Chesapeake Bay. Mar Ecol Prog Ser 67: 105-126

> Holland AF, Mountford NK, Mihursky J (1977) Temporal variation in upper bay and mesohaline communities. I. The 9-m mud habitat. Chesap Sci 18:370-378

> Honkoop PJC, Beukema JJ (1997) Loss of body mass in winter in three intertidal bivalve species: an experimental and observational study of the interacting effects between water temperature, feeding time and feeding behavior. J Exp Mar Biol Ecol 212:277-297

> Honkoop PJC, van der Meer J (1998) Experimentally induced effects of water temperature and immersion time on reproductive output of bivalves in the Wadden Sea. J Exp Mar Biol Ecol 220:227-246

> Honkoop PJC, van der Meer J, Beukema JJ, Kwast D (1999)

Editorial responsibility: Roderick Finn,

Bergen, Norway
Reproductive investment in the intertidal bivalve Macoma balthica. J Sea Res 41:203-212

Kamermans P, Van der Veer HW, Witte JIJ, Adriaans EJ (1999) Morphological differences in Macoma balthica (Bivalvia, Tellinacea) from a Dutch and three southeastern United States estuaries. J Sea Res 41:213-224

Kang DH, Ahn IY, Choi KS (2003a) Quantitative assessment of reproductive condition of the Antarctic clam, Laternula elliptica (King \& Broderp), using image analysis. Invertebr Reprod Dev 44:71-78

> Kang SG, Choi KS, Bulgakov AA, Kim Y, Kim SY (2003b) Enzyme-linked immunosorbent assay (ELISA) used in quantification of reproductive output in the Pacific oyster, Crassostrea gigas, in Korea. J Exp Mar Biol Ecol 282:1-21

Levitan DR (1995) The ecology of fertilization in free-spawning invertebrates. In: McEdwards L (ed) Ecology of marine invertebrate larvae. CRC Press, Boca Raton, FL, p 123-156

Matthew WD, Sandrock AW Jr (1987) Cyclophosphamide treatment used to manipulate the immune response for the production of monoclonal antibodies. J Immunol Methods 100:73-82

Meehan BW (1985) Genetic comparison of Macoma balthica (Bivalvia, Telinidae) from the eastern and western North Atlantic Ocean. Mar Ecol Prog Ser 22:69-76

Morgan SG (1995) Life and death in the plankton: larval mortality and adaptation. In: McEdwards L (ed) Ecology of marine invertebrate larvae. CRC Press, Boca Raton, FL, p 279-322

Ottinger CA, Lewis TD, Shapiro DA, Faisal M, Kaattari SL (2001) Detection of Perkinsus marinus extracellular proteins in tissues of the eastern oyster Crassostrea virginica: potential use in diagnostic assays. J Aquat Anim Health 13:133-141

Park KI, Choi KS (2004) Application of enzyme-linked immunosorbent assay for studying of reproduction in the Manila clam Ruditapes philippinarum (Mollusca: Bivalvia). I. Quantifying eggs. Aquaculture 241:667-687

Park KI, Choi JW, Choi KS (2003) Quantification of reproductive output of the butter clam, Saxidomus purpuratus (Sowerby, 1852) using enzyme-linked immunosorbent assay (ELISA). Ocean Polar Res 25:1-8

Powers SP, Peterson CH, Christian RR, Sullivan E, Powers MJ, Bishop MJ, Buzzelli CP (2005) Effects of eutrophication on bottom habitat and prey resources of demersal fishes. Mar Ecol Prog Ser 302:233-243

> Sconzo G, Palla F, Agueli C, Spinelli G, Giudice G, Cascino D, Geraci F (1999) Constitutive hsp70 is essential to mitosis during early cleavage of Paracentrotus lividus embryos: the blockage of constitutive hsp70 impairs mitosis. Biochem Biophys Res Commun 260:143-149

Seitz RD, Marshall LS, Hines AH, Clark KL (2003) Effects of hypoxia on predator-prey dynamics of the blue crab Callinectes sapidus and the Baltic clam Macoma balthica in Chesapeake Bay. Mar Ecol Prog Ser 257:179-188

Shaw WN (1965) Seasonal setting patterns of five species of bivalves in the Tred Avon River Maryland. Chesap Sci $6: 33-37$

Stillman RA, West AD, Goss-Custard JD, McGrorty S and others (2005) Predicting site quality for shorebird communities: a case study on the Humber estuary, UK. Mar Ecol Prog Ser 305:203-217

Väinölä R (2003) Repeated trans-Arctic invasions in littoral bivalves: molecular zoogeography of the Macoma balthica complex. Mar Biol 143:935-946

Submitted: October 26, 2007; Accepted: June 16, 2008

Proofs received from author(s): July 29, 2008 